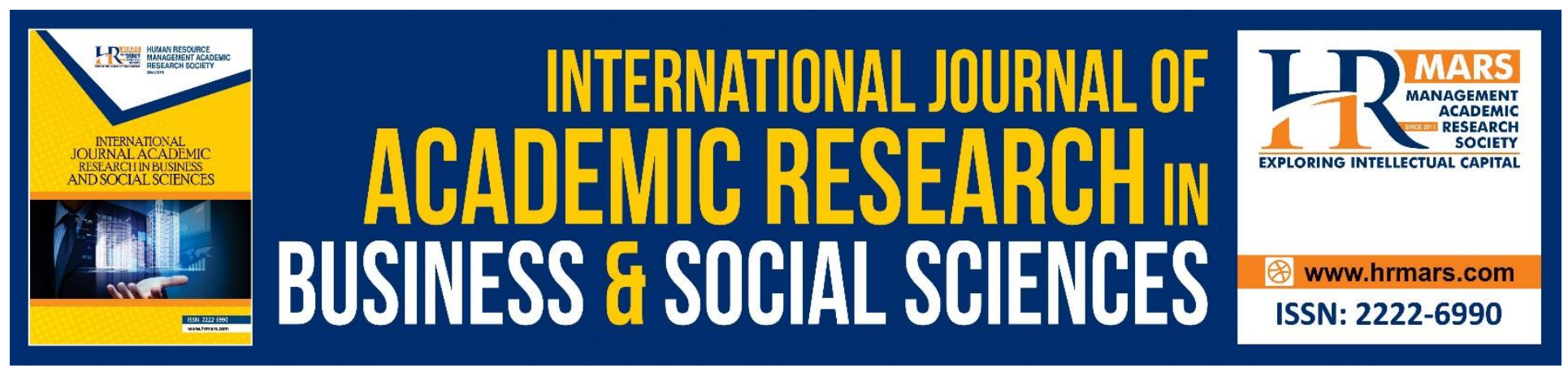

\title{
The Relationship Between Cultural Types According to Handy's Model and Organizational Structure in Jordanian Public Universities
}

Moath Amin Nasaireh, Abdul Hakim Abdullah, Khaled Ahmad Obeidat

To Link this Article: http://dx.doi.org/10.6007/IJARBSS/v9-i1/5495 DOI: $10.6007 /$ IJARBSS/v9-i1/5495

Received: 14 Dec 2018, Revised: 20 Jan 2019, Accepted: 26 Jan 2019

Published Online: 12 Feb 2019

In-Text Citation: (Nasaireh, Abdullah, \& Obeidat, 2019)

To Cite this Article: Nasaireh, M. A., Abdullah, A. H., \& Obeidat, K. A. (2019). The Relationship Between Cultural Types According to Handy's Model and Organizational Structure in Jordanian Public Universities. International Journal of Academic Research in Business and Social Sciences, 9(1), 973-985.

Copyright: (C) 2019 The Author(s)

Published by Human Resource Management Academic Research Society (www.hrmars.com)

This article is published under the Creative Commons Attribution (CC BY 4.0) license. Anyone may reproduce, distribute, translate and create derivative works of this article (for both commercial and non-commercial purposes), subject to full attribution to the original publication and authors. The full terms of this license may be seen

at: http://creativecommons.org/licences/by/4.0/legalcode

Vol. 9, No. 1, 2019, Pg. 973 - 985

http://hrmars.com/index.php/pages/detail/IJARBSS

JOURNAL HOMEPAGE

Full Terms \& Conditions of access and use can be found at http://hrmars.com/index.php/pages/detail/publication-ethics 


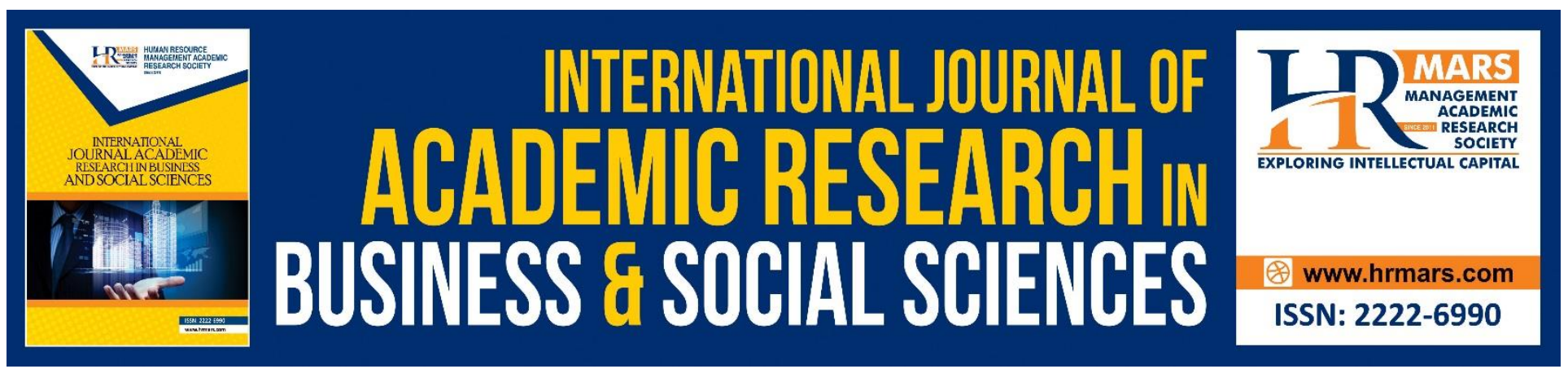

\title{
The Relationship Between Cultural Types According to Handy's Model and Organizational Structure in Jordanian Public Universities
}

\author{
Moath Amin Nasaireh, Abdul Hakim Abdullah, Khaled Ahmad \\ Obeidat \\ ${ }^{* 1}$ Faculty of Islamic Contemporary Studies, Universiti Sultan Zainal Abidin \\ E-mail: moathameen88@gmail.com, hakimabd@unisza.edu.my,k.obeidat@yahoo.com
}

\begin{abstract}
The aim of this paper is to examine the relationship between organizational culture and organizational structure. Therefore, 354 academic and administrative members from 3 public universities in Jordan have been chosen in order to highlight the relationship between their organizational culture and organizational structure. Organizational culture scale developed by Harrison \& Stokes (1992) and organizational structure scale developed by Gougui (2017) have been used during the preparation of the study questions. Factor analysis, reliability analysis and Pearson correlation analysis have been the major statistical indicators of data analysis. Correlation analysis results indicate that there is a medium level $(r=0,530)$, positive and significant $(p<0,01)$ relationship between organizational culture and organizational structure and there is not a significant statistical relationship between power culture (sub-dimension of organizational culture) and internal communication (sub-dimension of organizational structure). On the other hand, there is a significant, but weak relationship, between power culture (sub-dimension of organizational culture) and other sub-dimensions of organizational structure. There is a medium level statistical relationship between person culture (sub-dimension of organizational culture) and organizational complexity (subdimension of organizational structure). Moreover, it is observed that, there is a statistical significant relationship between sub-dimensions of organizational culture and organizational structure except the power culture (sub-dimension of organizational culture) and managerial attitude toward change (sub-dimension of organizational structure). Finally, it is also observed that, there is a significant statistical relationship between role culture, task culture and the rest of the organizational structure sub-dimensions except organizational complexity.
\end{abstract}

Keywords: Organizational Culture, Organizational Structure, Cultural Dimensions, Structural Dimensions, Jordanian Public Universities. 


\section{Introduction}

Organizational structure and organizational culture belong to the concepts of the highest explanatory and predictive power in understanding the causes and forms of people's behaviors in organizations. Consequently, these two concepts are often used in research as independent variables in explanations of numerous phenomena found in companies and other types of organizations. The relationship between organizational structure, culture and other components of management are usually examined separately and independently from one another. However, there are examples of research that analyze the relationship between management of both culture and structure in their mutual interaction (Wei et al., 2011; Singh, 2011; Zheng, et al., 2010). Unfortunately, although it is intuitively clear that organizational culture and organizational structure should have a great impact on each other, there has been very little extensive research examining their mutual impact. Hence, this study seeks to analyze the relationship between organizational culture and organizational structure in Jordanian public universities. Accordingly, this paper aims to answer the following research questions:

- What is the level of organizational culture and organizational structure in Jordanian public universities?

- What is the relationship between organizational culture and organizational structure in Jordanian public universities?

- What is the relationship between sub-dimensions of organizational culture and subdimensions of organizational structure in Jordanian public universities?

\section{Literature Review \\ Organizational Structure}

There is no one specific definition of organizational structure. However, usually organizational structure is defined as the formal allocation of work roles and administrative mechanism used to integrate and control work activities (Fengjing \& Chunsheng, 2010).

The structure of an organization is often defined as a set of ways in which the organization divides its human resource into distinct tasks and coordinates them (Mintzberg, 1979; Wilden et al., 2013). Slater et al. (2010) adds that the organizational structure is typically divided by three levels, namely formalization or the degree to which decisions and working relationships are governed by formal rules and procedures, centralization or the degree to which decision authority is closely held by top managers or is delegated to middle and lower level managers and specialization or the extent to which the organization employs experts or generalists.

Zhou et al. (2010) points out that organizational structure plays an essential role in a business organization. According to the study, organizational structure helps in organizing and coordinating activities such as the integration of resources in various divisions, formulation of business strategy, making full use of advantages in international research cooperation and seeking more external resources. In addition, another study by Kaplan and Poole (2012) finds that organizational structures have the ability to change and create complexity, offer the ideas and concepts for change as well as develop organizational climate that favours risk-taking and the motivation for change. They reveal that organizational structures can enhance innovation because they are relatively flexible and can be changed easily. Due to their flexibility and the change ability, the structures can encourage 
INTERNATIONAL JOURNAL OF ACADEMIC RESEARCH IN BUSINESS AND SOCIAL SCIENCES

Vol. 9, No. 1, Jan, 2019, E-ISSN: 2222-6990 @ 2019 HRMARS

employees' effective participation, open communication, develop team processes that can mobilize employees' skills and knowledge, help in effective problem solving and gain employees "buy-in" which facilitates the changes implementation.

\section{Organizational Culture}

One of the most important factors that affect organizational structure is organizational culture. Organizational culture guides the organization members to feel, learn and set the principles, expectations, patterns, behaviours and norms that promote high levels of achievements by facilitating the acceptable solution in knowing the problems (Schein, 1992; Armstrong, 2004).

Organizational culture is the set of important assumptions-often unstated- that members of an organization share in common. The two major assumptions in common are beliefs and values. Beliefs are assumptions about reality that are derived and reinforced by experience. Values are assumptions about ideals that are desirable and worth to be sought for (Muya \& Wesonga, 2012). Organizational culture is very important factor because it is the most rooted element that defines the organization and considered as the right way for many of organizations members. Nowadays, the business environment is very difficult due to the fast-changing demands, that lead to organizations restructuring and often leaving the employees to feel unimportant in the management process. The employees will have the feeling of being a part of the management process if their organization is well-organized and have a strong culture. A deep-rooted culture is as important as the knowledge when the moment of changing is needed. For a smooth and successful change of organizational culture, every employee needs to have a proactive approach and to work side by side with others. By doing so, proper solutions can be found. Such solutions will help the organization to be changed as planed and to sustain the new expected growth period that comes along with the change. The purpose of such change will help the organization to prosper and achieve its target; this also can be achieved most of the time by following the rules and values that are established within the organization. By this we understand the importance of values that exist in organizational culture (Tanase, 2015).

\section{Cultural Types According to Handy's Model}

Charles Handy's model of studying culture promptes researchers to use it to link organizational structure to culture. Handy (1996) identifies four types of cultures, namely 'Power Culture', 'Role Culture', 'Task Culture' and 'Person Culture'. Power culture relates to the extent to which a central figure (a leader) influences others in the organization. Role culture, bureaucratic in nature, relates to how work should be structured and procedures to be followed in accomplishing tasks. This type of organizational culture does not encourage the use of initiative in carrying out one's duties. Task culture is job-oriented because influence in the organization depends on the level of expertise of the central figure as opposed to personal authority. Person culture is an unusual culture where the individual is the focal point. In this type of culture, organization exists to help individuals and not the individuals helping the organization.

Handy (1993) argues that each of the above types of cultures may be fine, but sometimes, employees are often inflexible with regards to culture. This means that they often believe in the myth that what works well in one organization may also be successful in another (1993:183). In addition, 
INTERNATIONAL JOURNAL OF ACADEMIC RESEARCH IN BUSINESS AND SOCIAL SCIENCES

Vol. 9, No. 1, Jan, 2019, E-ISSN: 2222-6990 (C) 2019 HRMARS

Handy (1993) adds that an employee who is successful in one type of culture may not always do well in another (1993:204). Moreover, it is up to the executive of the organization to handle all four cultures, to distinguish and to amalgamate with them (Handy 1993:216).

\section{The Relationship Between Organizational Culture Types and Organizational Structure}

Organizational culture impact on effectiveness and efficiency of doing business in enterprises is partially and indirectly realized through organizational structure, affecting its two dimensions in this way: formalization level needed for the purpose of coordination and decision centralization level (Janicijevic, 2003: 180-182). Organizational culture affects the organizational structure formalization level and its choice of coordination mechanism through its connection to uncertainty, changes and the risk (Hofstede, 2011). Namely, if the organizational structure contents involve the tolerance of risk and uncertainty, the level of organizational structure formalization will be lower and vice versaif organizational culture has deep-seated opposition to risk and uncertainty, the organizational structure level will be higher. The decision-making centralization level in an enterprise is affected by so called the power distance. In this connection, the power distance is, as defined by Hofstede, the level at which the members of a culture accept the fact that the power is unequally distributed in the social system (Hofstede, 2011). With regard to this study, The presented classifications of organizational cultures and organizational structure models indicate a high level of accordance between the criteria used for differentiating organizational culture types (power culture, role culture, task culture, and people culture) and organizational models. The assumptions of suitable distribution of power within an organization, based on which organizational cultures are differentiated, are evidently connected with centralization level, based on which organizational structure models are distinguished. On the other hand, assumptions regarding the suitable form of collective action in an organization, based on which organizational cultures are differentiated, are evidently related to the formalization level in models of organizational structure (Janićijević, 2013).

The power distance in organizational structure implies the high decision-making centralization level/ autocratic style of leadership/ while the low distance power implies decisionmaking decentralization /democratic style of leadership (Janicijevic, 2003). Operating through the given dimensions, organizational structure considerably affects the structural type of the enterprise. Thus, the connection between organizational culture and organizational structure types is shown in the Table 1. 
INTERNATIONAL JOURNAL OF ACADEMIC RESEARCH IN BUSINESS AND SOCIAL SCIENCES Vol. 9, No. 1, Jan, 2019, E-ISSN: 2222-6990 (C) 2019 HRMARS

Table 1: Mutual correspondence of organizational culture types and organizational structure models

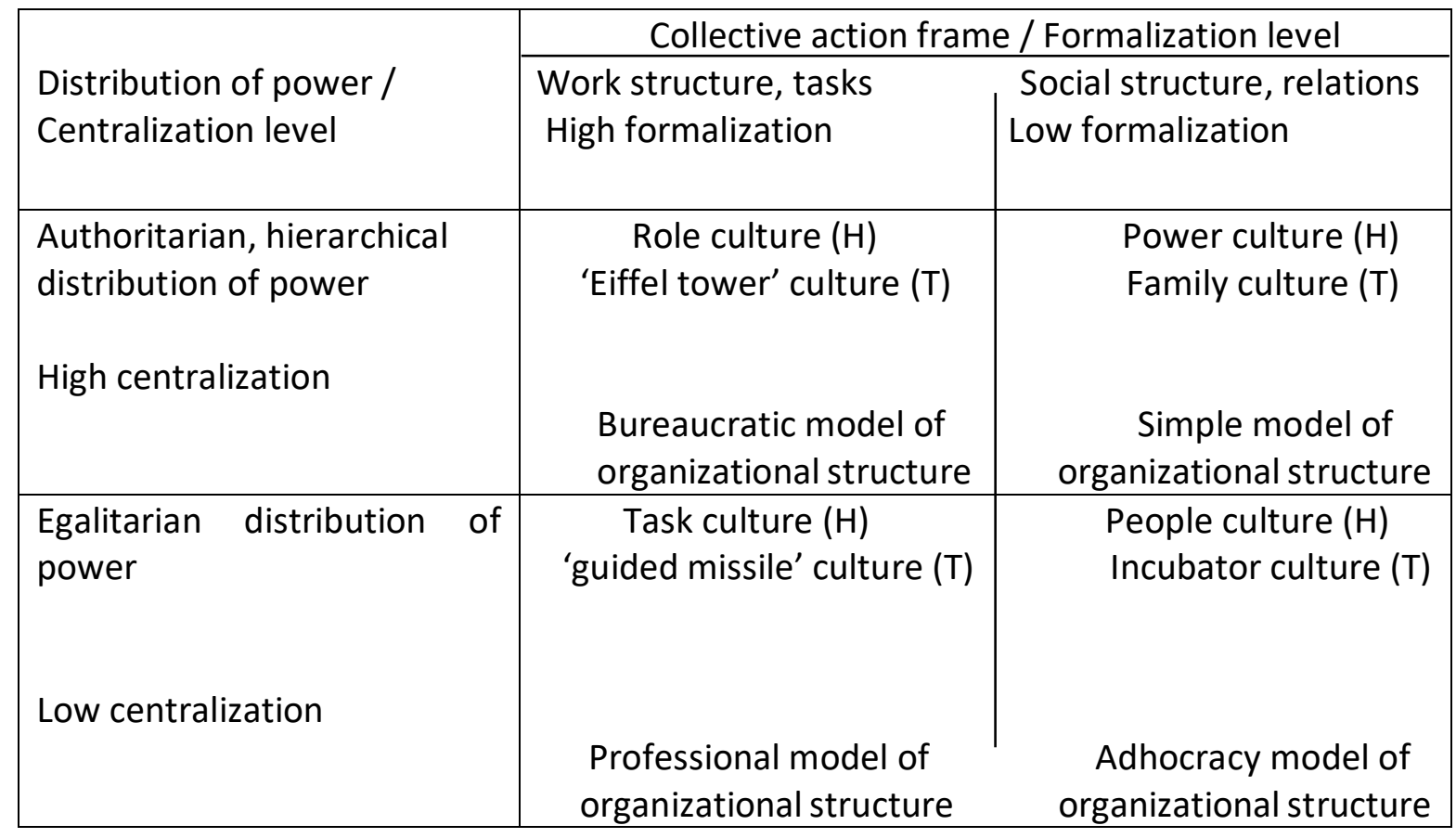

Hence, it is evident that organizational culture and structure are mutually connected. This connection is for the most part realized through two processes: culture institutionalization and structure legitimization. On one hand, culture institutionalization is the process in which assumptions, beliefs and values in enterprises are embedded in its structure. On the other hand, structure legitimization is accepting structure by employees because it conforms to their cultural assumptions, beliefs and values (Delic \& Nuhanovic, 2010). The relationship between organizational culture and structure is affected and in turn affects a number of phenomena as action, historical accountability, the concept of culture itself, and the meaning one gives to the association of these notions (Cutajar, 2013). Hays (1994) describes how various theorists in particular anthropologists, treat culture as a structure. whilst others, in particular sociologists, treat culture as distinct from structure (Cutajar, 2013).

\section{Research Methodology and Hypotheses}

The aim of this paper is to examine the relationship between organizational culture types and organizational structure in public universities in Jordan. Therefore, 354 academic and administrative members from 3 public universities have been selected in this study in order to highlight the relationship between their organizational culture and organizational structure. Research hypotheses are as follows:

H1: There is a significant relationship between organizational culture and organizational structure.

H2: There is a significant relationship between sub-dimensions of organizational culture and subdimensions of organizational structure. 
INTERNATIONAL JOURNAL OF ACADEMIC RESEARCH IN BUSINESS AND SOCIAL SCIENCES

Vol. 9, No. 1, Jan, 2019, E-ISSN: 2222-6990 @ 2019 HRMARS

\section{Data Collection and Analysis}

Survey method has been used in this research for data collection. Survey is consisted of 3 major parts and 43 questions in total. The first part of the questionnaire is made up of demographic questions. The second part of the questionnaire is consisted of organizational culture types, which was developed as scale by Harrison \& Stokes (1992). Finally, the third part is consisted of organizational structure developed as scale by Gougui (2017). Descriptive statistics has been used in order to highlight the demographic information of survey responders and to identify the levels of organizational culture types and organizational structure. Moreover, correlation analysis has been chosen to indicate the relationship between organizational culture types and organizational structure. On the other hand, factor analysis is applied to figure out the structural validity while Cronbach's Alpha coefficient is calculated to stress the reliability of internal consistency.

Correlation coefficients has been interpreted according to Table 2, mentioned by Özdamar (2003).

Table 2 Correlation Coefficient Values

\begin{tabular}{|lc|}
\hline \multicolumn{2}{|c|}{ Correlation Coefficient } \\
\hline Too Low Relationship & $0,00-$ \\
0.20 & \\
Low Relationship & $0,21-$ \\
0,40 & \\
Medium Relationship & $0,41-$ \\
0,60 & \\
High Relationship & $0,61-$ \\
0,80 & \\
Too High Relationship & $0,81-$ \\
1,00 & \\
\hline
\end{tabular}


INTERNATIONAL JOURNAL OF ACADEMIC RESEARCH IN BUSINESS AND SOCIAL SCIENCES

Vol. 9, No. 1, Jan, 2019, E-ISSN: 2222-6990 (C) 2019 HRMARS

\section{Research Finding}

Demographic information of questionnaire responders is mentioned below on Table 3.

Table 3: Distribution of Survey Responders According to Demographic Information

\begin{tabular}{|c|c|c|c|c|}
\hline Variable & Group & $\begin{array}{c}\text { Numbe } \\
r\end{array}$ & $\begin{array}{c}\text { Percentage } \\
(\%)\end{array}$ & Total \\
\hline \multirow[t]{2}{*}{ Gender } & Male & 269 & $75.9 \%$ & \\
\hline & Female & 85 & $24.1 \%$ & $100 \%$ \\
\hline \multirow[t]{6}{*}{ The University } & University of & 148 & $42.3 \%$ & \\
\hline & Jordan & 105 & $29.4 \%$ & \\
\hline & Yarmouk & 101 & $28.3 \&$ & $100 \%$ \\
\hline & University & & & \\
\hline & Mu'tah & & & \\
\hline & University & & & \\
\hline \multirow[t]{2}{*}{ Functions } & Academic & 281 & $79.4 \%$ & \\
\hline & Administrative & 73 & $20.6 \%$ & $100 \%$ \\
\hline \multirow[t]{5}{*}{ Rank } & Co-professor & 59 & $16.7 \%$ & \\
\hline & Assistant & 121 & $34.1 \%$ & \\
\hline & Professor & 66 & $18.6 \%$ & \\
\hline & Doctor & 108 & $30.6 \%$ & $100 \%$ \\
\hline & Lecturer & & & \\
\hline \multirow[t]{3}{*}{ Experience } & $<10 y r s$ & 98 & $27.6 \%$ & \\
\hline & 10-15yrs & 168 & $47.4 \%$ & \\
\hline & $>15 y r s$ & 88 & $25.0 \%$ & $100 \%$ \\
\hline
\end{tabular}

On the other hand, Cronbach's Alpha coefficient values are shown on Table 4. Table 4 below is used to analyse reliability; it shows that the scales were internally reliable as follows: Organizational culture (alpha 0.904) and organizational structure (alpha 0.944). Therefore, all the alpha values well exceeded the minimum standard (0.70) as suggested by Hair (2007).

Table 4: Cronbach's Alpha coefficient Values of Dimensions of Scale

\begin{tabular}{|c|c|c|c|}
\hline Constructs & Items & $\begin{array}{c}\text { Cronbach's } \\
\text { Alpha }\end{array}$ & Decision \\
\hline Organizational Culture & 29 & 0.904 & Achieved \\
\hline Organizational structure & 14 & 0.944 & Achieved \\
\hline
\end{tabular}


INTERNATIONAL JOURNAL OF ACADEMIC RESEARCH IN BUSINESS AND SOCIAL SCIENCES

Vol. 9, No. 1, Jan, 2019, E-ISSN: 2222-6990 @ 2019 HRMARS

Descriptive statistics of levels of Organizational Culture Types and Organizational Structure

Table 5: Descriptive Statistics

\begin{tabular}{|l|c|c|c|}
\hline & N & Mean & Std. Deviation \\
\hline Role Culture & 354 & 8.3282 & 1.38926 \\
\hline Task Culture & 354 & 7.9639 & 1.01869 \\
\hline Person Culture & 354 & 7.8487 & 1.15713 \\
\hline Power Culture & 354 & 7.3817 & 1.41318 \\
\hline Organizational Structure & 354 & 7.9198 & 1.07070 \\
\hline \multicolumn{1}{|c|}{ Valid N (listwise) } & 354 & & \\
\hline
\end{tabular}

Table 5 shows the mean values for power culture, role culture, task culture, person culture and organizational structure. Accordingly, Table 6 below describes the values for all level of constructs.

Table 6: Mean Score of Implantation

\begin{tabular}{|c|c|c|}
\hline No & Mean score & Implantation stage \\
\hline 1 & 1.00 to 4.00 & low \\
\hline 2 & 4.01 to 7.00 & Moderate \\
\hline 3 & 7.01 to 10.00 & High \\
\hline
\end{tabular}

Source: Koh (2014)

\section{Descriptive Statistics of Power Culture}

Based on Table 5, the level of power culture is high based on mean score of implantations as shown in Table 6. The level of power culture is in the $4^{\text {th }}$ rank and it is the lowest value in Jordanian Public universities when compare the other constructs in the organizational culture. In this type of culture, the focus is on decisiveness, and the leader (president is strong in his presence, cares for himself, rewards and protects his loyal followers regardless of competence, as long as they satisfy the leader's desires and personal needs even if it opposes to the requirements of the work, leaders did not refer to their supreme administrators even if they were wrong).

\section{Descriptive Statistics of Role Culture}

As shown in the types of culture in Table 5 above, the role culture occupies the first rank in Jordanian public universities. This type of culture focuses on regulations and stability as judging the employees' performance in Jordanian public universities depends on many variables. Such variables are job descriptions, rewarding employees based on their commitment to regulations. However, the employees follow the rules even if they disagree with business requirements.

\section{Descriptive Statistics of Task Culture}

Similarity, the task culture occupies the second rank in Jordanian public universities. The task culture focuses on success, growth and excellence. Therefore, employees realize the importance of achieving goals within short and limited time. The employees are self-directed and willing to work, rules and regulations are not allowed to be an obstacle in the way of work, employees work long without 
INTERNATIONAL JOURNAL OF ACADEMIC RESEARCH IN BUSINESS AND SOCIAL SCIENCES

Vol. 9, No. 1, Jan, 2019, E-ISSN: 2222-6990 (C) 2019 HRMARS

complaint and sacrifice their personal needs to achieve the interests of work with high moral and team spirit.

\section{Descriptive Statistics of Person Culture}

The person culture ranks in the third level in Jordanian public universities as shown in Table 6, where people sympathize with each other and give a part their time to others. The employees feel that the organization appreciates their efforts, they appreciate each other and like to spend time together outside the work time and focusing on human relationships but without ignoring the importance of work. Accordingly, employees are rewarded equally regardless of achievement.

\section{Descriptive Statistics of Organizational Structure}

Table 5 shows the level of the organizational structure in Jordanian public universities. Based on Table 5 , it is shown that the organizational structure determines the various departments and administrations of any organization by defining the lines of power, decision-making centers, communication between presidents and subordinates, the scope of supervision and the degree of centralization.

By the appropriate applying of the organizational structure in Jordanian public universities, restructuring is one of the important areas in question. This axis illustrates the reality of the organizational structure through the opinions of the respondents, whose results show that their views are positive towards the organizational structure as a dimension of organizational development.

\section{Correlation Analysis Results}

Correlation analysis results, as shown on Table 7 , indicate that there is a medium level $(r=0,530)$, positive and significant $(p<0,01)$ relationship between organizational culture and organizational structure. In other words, any increase in organizational culture also leads to an increase in organizational structure.

Table 7: Results of Correlation Analysis among Organizational Culture and Organizational Structure

$\begin{array}{cc}\begin{array}{c}\text { Organizational } \\ \text { Culture }\end{array} & \begin{array}{c}\text { Organizational } \\ \text { Structure } \\ 0,530 * *\end{array} \\ \text { Correlation } \\ \text { Sig. (2-tailed) } \\ \text { Sum of Squares } \\ \text { and Cross- } \\ \text { products } \\ \text { Covariance } \\ \mathrm{N}\end{array}$

. Correlation is significant at the 0.01 level (2-tailed).

On the other hand, research results of correlation analysis concerning the relationship between subdimensions of organizational culture and sub-dimensions of organizational structure are stressed on Table 8 below. Table 8 represents the results of Pearson Correlation analysis which identifies the 
INTERNATIONAL JOURNAL OF ACADEMIC RESEARCH IN BUSINESS AND SOCIAL SCIENCES

Vol. 9, No. 1, Jan, 2019, E-ISSN: 2222-6990 (C) 2019 HRMARS

relationship between sub-dimensions of organizational culture and sub-dimensions of organizational structure.

Table 8: Results of Correlation Analysis among Dimensions of Organizational Culture and

Dimensions of
Factor
Power Culture
Role Culture
Task Culture
Person Culture

\section{Organizational Complexity}

.612

.550

.612

.595

Internal
Communication
$* .490$
.810
.788
.790

Managerial Attitude Toward Change

.615

$* .814$

.763

.755

According to the results, there is not a significant statistical relationship between power culture (subdimension of organizational culture) and internal communication (sub-dimension of organizational structure). On the other hand, there is a significant, but weak, relationship between power culture (sub-dimension of organizational culture) and other sub-dimensions of organizational structure. There is a medium level statistical relationship between person culture (sub-dimension of organizational culture) and organizational complexity (sub-dimension of organizational structure). Moreover, it is observed that, there is a statistically significant relationship between sub-dimensions of organizational culture and organizational structure except the power culture (sub-dimension of organizational culture) and managerial attitude toward change (sub-dimension of organizational structure). Finally, it is also observed that, there is a significant statistical relationship between role culture, task culture, person culture and the rest of the organizational structure sub-dimensions except organizational complexity.

According to research findings, $\mathrm{H} 1$ is accepted. On the other hand, $\mathrm{H} 2$ is partly accepted for specific sub-dimensions of organizational culture and sub-dimensions of organizational structure.

\section{Conclusion}

Research findings expose that there is a statistically significant and positive relationship between organizational culture and organizational structure, in addition to statistically significant relationship between most of their sub-dimensions.

Adaptation of organizational goals and appropriation by employees are highly dependent on the rational selection of members who working in Jordanian public universities with high potential of embracing organizational values. In this context, this process is directly related to organizational structure policies of these universities. Thus, the sequencing and good management of the organizational structure makes the university at high level of overall organizational development achievement.

Exploring the relationship between organizational structure and organizational culture is highly beneficial, since both of them determine the behaviours of organization members, which can be achieved in different ways. Organizational culture is a core factor of organizational behaviour as it directs the way people behave within an organization by determining assumptions, values, norms, and attitudes according to which organization members guide themselves in everyday actions within 
the organization. On the other hand, organizational structure is an extrinsic factor which influences members' behaviour through formal limitations which are identified based on tasks divisions, authority distribution, working units and their coordination. Therefore, one's behaviour in an organization is the result of the impact of its culture and structure, as well as the influence of other factors. Accordingly, studying the mutual relationship of organizational culture and organizational structure is important for a comprehensive understanding of the behaviour of an organization's members.

\section{Acknowledgement}

Special appreciation is owed to prof Abdul Hakim Abdullah and Universiti Sultan Zainal Abidin (UniSZA), Research Management, Innovation \& Commercialization Centre (RMIC) UniSZA.

Corresponding Author: Moath Amin Nasaireh, Faculty of Islamic Contemporary Studies, Universiti Sultan Zainal Abidin, Gong Badak Campus, 21300 Kuala Terengganu, Terengganu, Malaysia.

Email: moathameen88@gmail.com

\section{References}

Armstrong, M. (2004). A handbook of human resource management practice, London.

Cutajar, B. (2013). The Impact of Organizational Culture on the Management of Employees' Talents: The Case of Maltese ICT Organizations (Doctoral dissertation, University of Leicester).

Delic, A., \& Nuhanovic, S. (2010). The Organizational Structure and Organizational Culture Interdependence Analysis with a Special Reference to Bosnian and Herzegovinian Enterprises. Economic analysis, 43(3-4), 70-86.

Fengjing, H., \& Chunsheng, S. (2010). Research on the Effects of Structure-oriented Organizational Innovation on Dynamic Core Competence of Enterprise. In Artificial Intelligence and Computational Intelligence (AICI), 2010 International Conference on (Vol. 3, pp. 157-160). IEEE. Gougui, A. (2017). Organizational structure, human resource practices, organizational culture and innovation activity among small and medium-sized enterprises in Algeria (Doctoral dissertation, Universiti Utara Malaysia).

Hair Jr, J. F. Money AH, Samouel P, Page M (2007). Research method in business.

Handy, C. (1993) Understanding Organizations, London-UK, Penguin Books Ltd, 4th Edition.

Handy, C. B. (1996). Gods of management: The changing work of organizations. Oxford University Press, USA.

Harrison, R., \& Stokes, H. (1992). Diagnosing organizational culture. Pfeiffer.

Hays, S. (1994) 'Structure and Agency and the Sticky Problem of Culture' in Sociological Theory, Vol. 12, No. 1, pp. 57-72.

Hofstede, G. (2011). Dimensional zing cultures: The Hofstede model in context. Online Readings in Psychology and Culture, 2(1), 1-26.

Janićijević, N. (2013). The mutual impact of organizational culture and structure. Economic annals, 58(198), 35-60.

Janićijević, N. D. (2003). Uticaj nacionalne kulture na organizacionu strukturu preduzeća u Srbiji. Economic Annals, 44(156), 45-66. 
Kaplan, H. B., \& Poole, M. S. (2012). Organizational innovation: Studies of program change in community agencies. Springer Science \& Business Media.

Mintzberg, H. (1979). The structuring of organization: A synthesis of the research. Prentice-Hall.

Muya, J. N. and Wesonga J. N. (2012). The Impact of Organizational Culture on Performance of Educational Institutions, International Journal of Business and Social Science, 3(8), 211-217.

Özdamar, K. 2003. Modern Bilimsel Araştırma Yöntemleri. Eskişehir: KaanKitabevi.

Schein, E. H. (1992). How can organizations learn faster?: the problem of entering the Green Room. Alfred P. Sloan School of Management, Massachusetts Institute of Technology.

Singh, S.K. (2011). Organizational Innovation as Competitive Advantage During Global Recession. The Indian Journal of Industrial Relations, 46(4), pp.165-185.

Slater, S. F., Olsen, E. M., \& Hult, G. T. (2010). Worried about Strategy Implementation?. Don't Overlook Marketing Role. Business Horizons, 53, 469-479.

Tănase, I. A. (2015). The importance of organizational culture based on culture transfer.". Management and Innovation for Competitive Advantage.

Wei L., Liu J. and Herndon N.C. (2011). SHRM and Product Innovation: Testing The Moderating Effects of Organizational Culture and Structure in Chinese Firms. The International Journal of Human Resource Management, 22 (1), pp. 19-33.

Wilden, R., Gudergan, S. P., Nielsen, B. B., \& Lings, I. (2013). Dynamic capabilities and performance: strategy, structure and environment. Long Range Planning, 46(1), 72-96.

Zheng W., Yang B. \& McLean G.N. (2010). Linking Organizational Culture, Structure, Strategy, and Organizational Effectiveness: Mediating Role of Knowledge Management. Journal of Business Research, 63, pp.763-771.

Zhou, M., Vaccaro, L. C., \& Qi, W. (2010, November). The Impact of Internationalization on Organizational Innovation. In Information Management, Innovation Management and Industrial Engineering (ICIII),2010 International Conference on (Vol. 3, pp. 78-81).IEEE. 